\title{
Analysis of Waiting Time Factors and Patient Satisfaction Level in Diseases Poly in Hospital dr. Sayidiman Magetan
}

\author{
Novita Eka Sari ${ }^{1}$, Indasah ${ }^{2}$, \\ Sentot Imam Suprapto ${ }^{2}$ \\ ${ }^{1}$ Magister of Health Study \\ Program of Institut Ilmu Kesehatan \\ STRADA Indonesia \\ ${ }^{2}$ Lecturer of Institut Ilmu \\ Kesehatan STRADA Indonesia \\ Email: \\ novitaekasari@gmail.com
}

Received : October 12, 2019

Accepted : February 13, 2020

Published : May 12, 2020

\begin{abstract}
Good health care is a community need and is often a measure of development success. Recognizing that health services are a necessity for every citizen, the government endeavors from time to time to produce programs that can improve overall health services. Therefore, hospitals are required to always maintain trust by taking into account the needs of patients in an effort to fulfill the wishes and expectations of the services provided. Patients not only expect medical and nursing services but also expect comfort, good accommodation. Qualitative research is defined as a research procedure that produces descriptive data. Data collection using techniques indepth interview with semi-structured questions with a sample of 15 informants. From the results of the study note that services related to Waiting time get related to the speed of service procedures for patient acceptance, the accuracy of doctor arrival time and the speed of action, readiness of doctors and nurses to serve patients, distribution of medical record files from the medical record room to each poly and the ability of nurses is very influential to determine patient satisfaction by the treatment that patients get.
\end{abstract}

Keywords: Service. Patient expectations, Waiting Time 


\section{INTRODUCTION}

Based on the Law of the Republic of Indonesia article 1 number 25 of 2009 concerning Public Services, the definition of public service is an activity or series of activities in order to meet service needs in accordance with statutory regulations for every citizen and population for services, goods, and / or administrative services provided by public service providers. Decree of the Minister of Administrative Reform No.63 / KEP / M.PAN / 7/2003, public services are all service activities carried out by public service providers in an effort to meet the needs of service recipients and the implementation of statutory provisions. (Permenkes RI, 2008 )

Hospital is a health facility that organizes individual health services including promotive, preventive, curative and rehabilitative services that provide inpatient, outpatient, and emergency services (Permenkes RI, 2008). Outpatient services as one type of service in hospitals that require quality assessment aspects, and nursing services are an integral part of hospital services. Overall interconnected, running integrated to provide services to users of hospital services so that nursing services is one of the determinants of service quality and hospital image in the eyes of the public (Permenkes RI, 2008).

Public hospitals as a health service facility play an important role in health development. Public hospitals have a mission to provide quality and affordable health services to the community in order to improve the degree of public health, while special missions are aspirations that are set and desired to be achieved by public hospital owners. General hospital is a hospital that provides health services for all types of diseases from basic to specialist. The main task of public hospitals is to carry out health efforts in an effective and successful manner to prioritize recovery and recovery efforts carried out in a harmonious and integrated manner with efforts to improve and prevent and carry out referral efforts (RI Minister of Health Decree Number 983 of 1992).

Outpatient services are specialist services carried out in hospitals whose availability of services are adjusted to the specifications of the hospital. At a minimum there must be a pediatric clinic, internal medicine clinic, midwifery clinic, and surgical clinic. The tendency of the community towards polyclinics is increasing to get practical treatment services that come once and on that day also receive a complete service (one day care). However, the community now this often makes time as a very valuable thing, so waiting time becomes a consideration for someone to choose and come to a hospital. Patient waiting time is defined as the length of time required from the patient registering until served by a specialist. Long waiting time is the second dissatisfaction factor after the friendship and friendliness of the officers. The patient's waiting time reflects how the organization manages the service components that are tailored to the patient's situation and expectations. What is felt by patients in waiting for services at the Hospital is an unpleasant feeling, because both are very undesirable. The quality of health services should be examined and addressed as best as possible so that customers remain loyal to the services provided. One aspect that needs to be improved is the quality of outpatient services. Therefore, hospitals are required to always maintain trust by taking into account the needs of patients in an effort to fulfill the wishes and expectations of the services provided. Patients not only expect medical and nursing services but also expect comfort, good accommodation.

Good health care is a community need and is often a measure of development success. Recognizing that health services are a necessity for every citizen, the government endeavors from time to time to produce programs that can improve overall health services. One of the programs organized by the Government of Indonesia is the implementation of the National Health Insurance (JKN) program organized by the Social Security Organizing Agency (BPJS) according to the Act (Law), namely Law Number 40 of 2004 concerning the National Social Security System (SJSN). The health insurance program is run nationally with the principle of social insurance, the principle of equity and the system in the form of a mutual assistance system where the able and healthy participants will help participants who are poor and sick (Kemenkes RI, 2014).

The 3 patients showed the patient waiting time between 80-100 minutes to get medical services, from the arrival of the patient to take the queue number to get an examination by a doctor. It is not uncommon for patients to directly submit their complaints because they wait too long to get an examination by a doctor, where the time to meet for a doctor feels too short when compared to the time spent waiting for a call to be examined by a doctor. 
As a result, there are still some patients who wait a long time to get outpatient services starting from the patient registering until the patient is called / entered into the clinic, which in the end will indirectly have an impact on patient satisfaction with the services provided in outpatient care (starting from registering until called / entered polyclinic room). Not a few still found complaints / complaints from some patients because of the problem of waiting time at the destination polyclinic in order to get medical services as soon as possible, so that the patient's condition still looks so crowded, and the patient looks bored and anxious because of the limited time available during hospitalization road, so there are still some patients who ask back to the registration officer or polyclinic officer related to outpatient services. (Ministry of Health, 2008)

In line with Nur Laeliyah 2017 research, Waiting Time for Outpatient Services with Patient Satisfaction with Outpatient Services in Indramayu District Hospital, Knowing the waiting time for outpatient services, the level of outpatient satisfaction with outpatient services, and the relationship between waiting time for services outpatients with patient satisfaction with outpatient services. This type of research is descriptive with a quantitative approach, and cross sectional design. The sample technique used is purposive sampling. The instruments of this study include the questionnaire, observation check list, and observation of time evaluation. Data analysis used univariate analysis and bivariate analysis with chi-square test. The mean waiting time for patient services in outpatients of RSUD Indramayu Regency is 70.18 minutes and most of the categories are long time (> 60 minutes). The level of satisfaction in the moderately satisfied category, based on the five dimensions of service quality is found in the dimensions of tangibles, responsiveness, assurance, and empathy in the moderately satisfied category while in the reliability dimension in the satisfied category. The relationship between waiting time for outpatient patient care and patient satisfaction with outpatient care at Indramayu District Hospital is indicated by $\mathrm{p}=0.042$ or korelasichi-square value of 4.135.

With a background above the Regional General Hospital dr. Sayidiman Magetan needs to develop the quality of human resources because it is deemed necessary to pay more attention to the smooth running of work tasks so that organizational goals will be achieved. For this reason, the authors are interested in making a Final Project Report entitled the analysis of waiting time factors and the level of patient satisfaction in the Internal Medicine Clinic of Dr. Sayidiman Magetan Hospital.

\section{METHODS}

In this study, researchers used a qualitative design that is a research procedure that produces descriptive data in the form of written or oral words from people and observed behavior. Moleong explained in a descriptive qualitative approach, the data collected was data in the form of words, pictures and not numbers. The data can be obtained from interviews, field notes, videos, photos and personal documentation. The results of this study are in the form of excerpts from interview transcripts that were previously processed and then presented descriptively. This study will explore the factors of waiting time and the level of patient satisfaction in the Internal Medicine Polyclinic of Dr. Sayidiman Magetan Hospital.

The number of samples of this study were 15 informants with a sampling technique using purposive sampling.

\section{RESULTS AND DISCUSSION}

\section{Process Process of Internal Medicine Poly Patients and Rights as Patients Can Be Fulfilled}

Health service facilities become important in health service organizations, increasing public awareness about health and health services encourages every health service organization to be quality conscious in providing services to users of health services. the quality of health services is health services that can satisfy every user of health services in accordance with the level of satisfaction of the average population and its organizers in accordance with professional standards and codes of ethics. (Munijaya, 2011). Emphaty, namely individual attention given to contact, ability to communicate, high attention from officers, ease in reaching locations, ease in paying and administering administration.

The speed and accuracy of the services provided by the officer will get the satisfaction value from the patient. This research shows that the registration section is generally good, although in terms of speed and timeliness are still not fulfilled what is mandated by the Ministry of Health in 2008 with a period of 10 to 15 minutes on average patients still need time to queue up in the sky still need more time of 15 minutes. The delay occurred with several obstacles between the BPJS system. 
Patient satisfaction is a valid reaction after receiving health services. It affects the decision to re-use that is continuous towards the use of the same service and will affect the delivery of messages / impressions to parties / others about the health services provided

In another study conducted by Torri 2016, Factors Influencing Health Service Waiting Times in relation to Outpatient Satisfaction of Diseases Clinics in RSUD Dr. Iskak Tulungagung. This study is to determine the factors that influence waiting time for health services in relation to outpatient satisfaction using descriptive analysis research design. The research data were obtained using a crosssectional approach, namely Time and Motion Study and Survey. The total sample in this study was 101 respondents consisting of 101 outpatients in the Internal Medicine Clinic Dr. Iskak Tulungagung. The results of multiple regression analysis show that patient satisfaction is influenced by the actual waiting time felt by the patient, and the speed of service received by the patient, the main factor that extends the waiting time of the service and decreases patient satisfaction, is the less optimal doctor schedule on duty.

In this study it was found that there were still many patients who complained about the length of the waiting time. Although there have been improvements made it has not fulfilled the wishes of the patient. According to the Decree of the Minister of Health RI Number 129 / Menkes / SK / II / 2008. Minimum service standards regulated in the service standards include the types of services, indicators, and minimum service standards, the standard waiting time for patients in outpatient installations (polyclinics) is less or equal to 60 minutes, including the time for the provision of medical record documents that are determined less than or equal to 10 minutes, it cannot be fulfilled by the hospital. As a result, the waiting time is longer.

In another study conducted by Neti $\mathrm{m}$. Bustani 2015. Analysis of the length of waiting time for outpatient services at the public health center in North Sulawesi Province. This study used a qualitative method by conducting interviews with 7 informants as primary data, while secondary data were obtained from direct observations / observations in BKMM North Sulawesi Province. The results of the study found that the arrival of patients at BKMM had occurred before the registration window was opened and most of the patients came with their families

Inadequate facilities / facilities, as well as long waiting times to get services. The low service performance will build a bad image at the hospital. Patient satisfaction is the first indicator of the hospital and a measure of service quality. Low patient satisfaction has an impact on the number of hospital visits, while nurses' attitudes towards patients will also have an impact on patient satisfaction, where the needs of patients over time will increase,

Patient satisfaction is defined: patient satisfaction with a comfortable waiting room in waiting for health services, patient satisfaction when getting services provided by health workers in the service room, by getting the expected services the possibility of referring friends or relatives for treatment to these health services

Assessment of Assurance, this dimension of certainty or guarantee is a combination of the competency dimension, meaning the skills and knowledge possessed by employees to perform services. Courtesy includes the friendliness, attention, and attitude of the employees. Credibility includes matters relating to trust in the company, such as reputation, achievement and so on.

Patients are sick people treated by doctors and other health professionals in the practice. While satisfaction is the feeling of pleasure someone comes from the comparison between pleasure of the activity and a product with expectations. states that satisfaction is the feeling of being happy or disappointed someone who appears after comparing between his perception or impression of the performance or results of a product and his expectations

Patients will feel satisfied if there are similarities between expectations and the reality of health services obtained. User Satisfaction health services have a close relationship with the results of services health, both medically and non-medically, such as compliance with treatment, understanding of medical information and continuity care

\section{Factor Analysis Waiting time and patient satisfaction in polyclinic in RSUD Dr. Sayidiman Magetan}

Waiting Times / waiting time is the length of time a patient waits for health services to get a prescription from a doctor, waiting for a long time causes dissatisfaction of the patient / customer outpatient service procedures will have an impact on the quality of service to the community, adequate 
facilities and easy access and complete hospital facilities will have an impact on patient / customer satisfaction with health service users.

Patient satisfaction in assessing good service quality, and is an important measurement that is fundamental to the quality of service. This is because it gives. information on the success of quality service providers with the values and expectations of patients who have their own authority to set standards of service that must be done

In this case the researchers produce subordinates to the factors that influence waiting time, namely the standard procedure of services provided to provide a diagnosis that is in accordance with patient complaints, the distribution of medical records files that have not been on time and the doctor's arrival time is not on time. One of the main ways to define health services including outpatient services is to establish quality health services, consistently higher than competitors. If the services experienced meet or exceed the patient's expectations they will be satisfied, they will use the healthcare provider again. The purpose of outpatient services is to provide consultation to patients who need the opinion of a specialist doctor, with treatment measures or not and to provide follow-up for inpatients who have been allowed to go home but are still under control of their health condition.

In another study, Henny Maria Ulfa 2017. The minimum service standard of waiting time in the registration of outpatients in Petala Bumi Rsud Riau Province. The research methodology used in this study is a descriptive approach with a combination of quantitative and qualitative, the sample for this study were 97 patients. Resulting in research waiting time in outpatient registration included in the slow category ( $\geq 10$ minutes) of 66 patients $(68.0 \%)$ while in the fast category ( $\leq 10$ minutes) 31 patients (31.9\%). Of 97 outpatients at Petala Bumi Hospital, Riau. From the workload by additional resource officers needed, especially in distribution so that medical staff work longer together, the education and training of medical officers records have been carried out, SPO in TPPRJ already exists but is not running optimally, and facilities in the hospital's medical record unit at Petala Bumi Riau is sufficient. Suggestions in this study are to improve the quality and quantity of staff so that patients do not wait longer in outpatient registration. Medical staff are expected to be able to carry out their duties in accordance with established SOPs so as to increase productivity values so that patient services are faster and can improve the quality of services at TPPRJ.

\section{Patient Expectations To Hospital Managers To Meet Public Service Standards And Meet Patient Expectations}

Researchers found that many complaints from patients as patients related to the length of waiting time needed to obtain medical services, although there have been efforts to improve the hospital management has tried to increase the number of doctors on duty, but it has not been able to resolve patient complaints related to waiting time. long.

The level of satisfaction of a person after comparing the performance or results he perceived compared with expectations. So satisfaction or dissatisfaction is the conclusion of the interaction between expectations and experiences after using the services provided.

Waiting time is one indicator that is easily seen, can be felt and objectively can be used in assessing service performance at the clinic. Broadly speaking, there are two elements that are directly involved and play an important role in determining the speed of service in the clinic, namely the medical records and doctors. Many people who complain and feel dissatisfied with the services provided by hospitals, both in terms of examinations that are not given enough attention by health workers, staff skills. Waiting is very boring especially when no guarantees are given

Factors Affecting Medical Service Quality Ali Mohammad MOSADEGHRAD School of Public Health, Tehran University of Medical Sciences, Tehran, Iran., 2013 discusses the factors identifying factors that influence the quality of medical services provided by iranian doctors, by conducting in-depth individual interviews performed with 64 doctors working in various medical institutions in Iran. Results: Individual, organizational, and environmental factors increase or hinder the quality of medical services. The qualification of medical services depends on the personal factors of the doctor and patient, and factors related to wider health care and environmental settings.

In this case the researchers found an effort to improve the services provided as conveyed by triagulation 1 informants now the service is much better and also the addition of doctors but patients still complain about the length of waiting time and patients expect improvement in service management, 
facilities such as additional seating TV and Wiifi facilities are to divert the feeling of boredom waiting for the queue

The key to this is customer satisfaction. So it is very important to provide the best service to customers. It can be said that customer service is providing everything for others that is done based on awareness to serve, looking forward, full of initiative, showing concern and always evaluating, one of which is conducting customer satisfaction surveys that have not gone well.

\section{CONCLUSION}

1. Outpatient is part of a hospital unit that serves patients with outpatient needs.

2. Outpatient services are activities related to polyclinic activities

3. In this study did not distinguish between old and new patients because it turned out that the difference between old patients and new patients was not related to the length of time to wait for services in internal medicine.

4. The handling of doctors in performing outpatient care is the main function of the clinic

5. Factors that affect response time, outpatient units need other supporting facilities such as: laboratory, radiology, pharmacy are the causes of the long waiting time, in addition to the appointment of a doctor.

\section{REFERENCES}

Andi Sofyan, Malpraktik Medis, Makasar: Pena Pres,2015

Ali, Zainuddin. Metode Penelitian Hukum. Sinar Grafika : Jakarta,2011

Arikunto Suharsimi, Prosedur Penelitian Suatu Pendekatan Praktek,, Jakarta: Binam Aksara, 2012

Ashshofa, Burhan. 2007. Metode Penelitian Hukum. Rineka Cipta : Jakarta

Endang wahyati yustina, 2012,Mengenal Hukum Rumah Sakit, bandung, keni media,

Herlambang,Susatyo. 2016, Manajemen Kesehatan Rumah Sakit.Yogyakarta: Gosyen Publishing.

Hermein hadiati koeswadji, (2002) hukum untuk perumahsakitan, citra aditya bakti, Bandung,

Moleong, Lexy J. 2005. Metode Penelitian Kualitatif. Bandung: PT Remaja Rosdakarya

Moleong, Lexy. 2007. Metodologi Penelitian Kualitatif. Bandung: PT Remaja Rosdakarya.

Moleong J, Lexy. 2011. Metode Penelitian Edisi Revisi. Bandung : PT RemajaRosdakarya Offset

Soebarto, KK. (2011). Tinjauan faktor-faktor yang mempengaruhi waktu tunggu pelayanan rekam medis di pendaftaran rawatjalan RSUD Datu Sanggul Rantau. Skripsi diterbitkan. Banjarbaru: Program Studi Perekam dan Informasi Kesehatan Stikes Husada Borneo Banjarbaru, diakses tanggal 24 April 2019, http://www.scribd.com/doc/13099535/Karya-Tulis-Ilmiah.

Stefanus Suprianto,Akssesbilitas Pelayanan Kesehatan di Indonesia, Yogyakarta: PT Kanisius,2016 Sugiyono. 2011. Metode Penelitian Kuantitatif Kualitatif, Bandung: Alfabeta

Sugiyono. 2012. Metode Penelitian Pendekatan Kuantitatif, Kualitatif dan R\&D.Bandung: Alfabeta Taufiqurokhman, Teori Perkembangan Menejemen Pelayanan Publik, Tang Sel,UMJ Press,2018

Purhantara Wahyu, metode penelitian kuantitatif untuk bisnis, Yogyakarta: Graha Ilmu 2010

Waluya, Bagja. 2007. Sosiologi, Menyelami Fenomena Sosial di Masyarakat. Bandung: PT. Setia

Purna Invers. 